\title{
Growth and Yield Performance of Solanum tuberosum Grown from Seed Potatoes Infected with 'Candidatus Liberibacter solanacearum' Haplotypes A and B
}

\author{
Kylie D. Swisher Grimm, ${ }^{1, \dagger}$ Tariq Mustafa, ${ }^{2}$ W. Rodney Cooper, ${ }^{3}$ and Joseph E. Munyaneza ${ }^{3}$ \\ ${ }^{1}$ United States Department of Agriculture-Agricultural Research Service, Temperate Tree Fruit and Vegetable Research Unit, \\ Prosser, WA, 99350 \\ ${ }^{2}$ Washington State University, Department of Entomology, Pullman, WA, 99164 \\ ${ }^{3}$ United States Department of Agriculture-Agricultural Research Service, Temperate Tree Fruit and Vegetable Research Unit, \\ Wapato, WA, 98951
}

\begin{abstract}
Zebra chip (ZC) disease of potato (Solanum tuberosum) is associated with infection by 'Candidatus Liberibacter solanacearum' (Lso). Two haplotypes of Lso-A and B-occur in the United States. Lso haplotype B is more virulent than haplotype A, causing greater disease incidence in tubers, more severe symptoms, and greater loss in tuber yield. This study assessed whether tubers from infected plants generate new infected plants the following year. The effects of both Lso haplotypes $\mathrm{A}$ and $\mathrm{B}$ on tuber resprout were examined on five potato cultivars.

and plants generated lower daughter tuber yields in weight and quantity. Plants generally emerged poorly from Lso B-infected tubers and produced lower daughter tuber yields than Lso A-infected tubers. Regardless of Lso treatment, all daughter tubers were asymptomatic, and only $0.3 \%$ tested positive for Lso in experiments conducted over 2 years. This suggests that plants generated from Lso A- and Lso Binfected seed potatoes with severe ZC symptoms are likely not a significant source of Lso in potato fields.
\end{abstract} When compared with noninfected tubers, overall plant emergence rate from Lso A- or B-infected tubers was lower, plants emerged slower,
Keywords: Lso, potato, zebra chip
During the past two decades, zebra chip (ZC) disease of potato has caused economic losses by reducing tuber quality throughout the western and central United States. The causal agent of the disease is 'Candidatus Liberibacter solanacearum' (Lso), which is transmitted to potato and other solanaceous plants including tomato by the potato psyllid, Bactericera cockerelli (Šulc) (Hemiptera: Triozidae). ZC disease was first identified in the early 2000s in southern Texas (Munyaneza et al. 2007a, 2007b; Secor et al. 2009). The geographic range of Lso radiated outward and first occurred in the Pacific Northwest (U.S. states of Idaho, Oregon, and Washington) in 2011 (Munyaneza 2012; Crosslin et al. 2012a, 2012b). Nearly all U.S. states west of the Mississippi river, and even Alberta, Canada, have now had reports of ZC disease (Henrickson et al. 2019; Munyaneza 2012). There are no methods to directly control Lso, so ZC disease is

Current address of T. Mustafa: Department of Entomology, University of Agriculture, Faisalabad, Pakistan

${ }^{\dagger}$ Corresponding author: K. D. Swisher Grimm;

kylie.swishergrimm@ars.usda.gov

The use of trade, firm, or corporation names in this publication is for the information and convenience of the reader. Such use does not constitute an official endorsement or approval by the United States Department of Agriculture or the Agricultural Research Service of any product or service to the exclusion of others that may be suitable. USDA is an equal opportunity provider and employer.

Funding: Funding was provided by U.S. Department of Agriculture Agricultural Research Service and U.S. Department of Agriculture Foreign Agricultural Service, Technical Assistance for Specialty Crops (TASC) program project \#2092-22000-021-17-R.

The author(s) declare no conflict of interest.

Accepted for publication 25 October 2019.

This article is in the public domain and not copyrightable. It may be freely reprinted with customary crediting of the source. The American Phytopathological Society, 2020. managed using insecticides to suppress populations of the insect vector. Growers in the Pacific Northwest and Texas have spent an estimated \$11 and \$26 million, respectively, annually on potato psyllid management following the initial outbreaks in these regions (CNAS 2006; Greenway and Rondon 2018).

The high cost for psyllid control is due in part to variability in the severity of ZC outbreaks among years and growing regions and to the inability to predict when or where $\mathrm{ZC}$ will occur. Proposed sources of $\mathrm{ZC}$ variability include biological differences among haplotypes of the psyllid vector and the pathogen. Potato psyllid occurs in at least four biologically distinct haplotypes, which differ in size, fecundity, presence of endosymbionts, feeding behavior, and host plant preference (Cooper et al. 2015, 2019; Horton et al. 2014; Liu et al. 2006; Mustafa et al. 2015a, 2015b; Swisher et al. 2012, 2014). Yet regardless of haplotype, psyllids that have already acquired Lso have equal capacity to vector the pathogen to potato (Mustafa et al. 2015b).

Seven haplotypes of Lso have been identified globally, but only three are known to occur in North America. Lso haplotypes A and $\mathrm{B}$ are typically associated with infection of solanaceous crops in the United States, Mexico, and Central American countries (Dahan et al. 2017; Nelson et al. 2011, 2013). Lso A also occurs in New Zealand (Liefting et al. 2008; Pitman et al. 2011). Recently, Lso haplotype $F$ has been described in a single potato tuber in southern Oregon, although the risk of this haplotype as a cause of ZC outbreaks has not yet been determined (Swisher Grimm and Garczynski 2019). All other described Lso haplotypes occur in Europe and Northern Africa and infect species within the Apiaceae (Lso haplotypes C, D, and E) or Urticaceae (Lso haplotype U) (Alfaro-Fernández et al. 2012, 2017; Haapalainen et al. 2018a, 2018b; Holeva et al. 2017; Munyaneza et al. 2011; Nelson et al. 2013; Tahzima et al. 2014; Teresani et al. 2014).

Lso haplotypes A and B, which are both associated with ZC disease in North America, differ in virulence and disease severity (Harrison et al. 2018; Swisher Grimm et al. 2018). Two independent studies on Lso infection of potato demonstrated that compared with infection by Lso haplotype A, haplotype B caused more severe symptoms, higher rates of symptom development, and greater yield reductions (Harrison et al. 2018; Swisher Grimm et al. 2018). A similar study in tomato also showed that symptoms caused by Lso haplotype 
B were more severe than those caused by haplotype A (MendozaHerrera et al. 2018). Commercial potatoes are grown not from true seed but by vegetative propagation of tubers (seed potatoes) from the previous growing season. Although several studies have examined the effects of Lso infection on the regrowth of seed tubers, no study has compared the effects caused by Lso haplotypes A and B. Two studies conducted in the United States before the identification of Lso haplotypes or with mixed infection showed that $\leq 50 \%$ of infected seed potatoes sprouted, and those that did produce new plants were apparently not infected with Lso (Henne et al. 2010; Rashed et al. 2015). However, another study conducted in New Zealand indicated that seed potatoes generated by plants infected with Lso haplotype A develop new plants infected with the pathogen (Pitman et al. 2011).

The goal of this study was to compare the growth and yield of potato plants grown from noninfected seed potatoes or from seed potatoes infected by Lso haplotypes A or B. This was achieved by infecting plants of five potato cultivars, storing the harvested tubers using standard industry methods, replanting the tubers the following growing season, and recording plant emergence rates and time, symptom development, presence of Lso, and tuber quality and quantity.

\section{Materials and Methods}

Sources of potato seed pieces. Generation 2, noninfected seed potatoes and seed potatoes infected at the tuber initiation stage (approximately 12 to 13 weeks prior to harvest) of the Atlantic, Ranger Russet, Russet Burbank, Russet Norkotah, and Umatilla Russet cultivars were produced in 2014 and 2015 at the USDA-ARS research farm near Moxee, WA (Swisher Grimm et al. 2018). Here, plants were grown in field cages and were infested with potato psyllids released at the base of each plant ( $n=3$ for colonies with 80 to $100 \%$ infection rate, and $n=5$ for colonies with 50 to $65 \%$ infection rate) from laboratory colonies infected with either Lso haplotype A or haplotype B (Swisher Grimm et al. 2018). Noninfested plants grown in cages were used to produce noninfected seed tubers. The mature tubers were harvested by hand in autumn of each year and stored at $10^{\circ} \mathrm{C}$. The following spring, each seed potato was bisected at the stem end prior to planting to verify that ZC symptoms were present in the inoculated tubers and that no symptoms were present in the healthy tubers. Symptom severity was ranked on a scale of 0 (no symptoms) to 3 (severe symptoms) as previously described (Rashed et al. 2013; Swisher Grimm et al. 2018). In both years of this study, nearly all tubers produced by plants infected with either Lso haplotype A or B exhibited severe symptoms, whereas tubers produced by noninfected plants were asymptomatic (Table 1 ).

Field design and experimental protocol. The field assays were conducted at the USDA-ARS research farm located near Moxee, WA, in 2015 and 2016 using seed potatoes produced during the previous growing season. In each year, hilled rows were generated with a buried irrigation drip line, and potato seed tubers were planted by hand at a depth of $15 \mathrm{~cm}$ in late May. Eight potato seed tubers of either ZC symptomatic Lso haplotype A or Lso haplotype B seed, or healthy potato seed, were planted in each field cage, at a space of roughly $20 \mathrm{~cm}$. Field cages were utilized to keep out insect pests, preventing any in-season spread of Lso and other insect-transmitted pathogens. Treatment combinations (cultivar by infection status) were arranged in a completely randomized design during both years. The number of cages included for each cultivar by treatment combination was dependent upon the number of available symptomatic seed potatoes produced during the previous growing season (Table 1).

Plant emergence dates were recorded from each potato seed tuber, and days to emergence were calculated for the individual plants at the end of the season, with the day planted as day 0 and the first day after planting as day 1. Following plant emergence, the health of the above-ground foliage was recorded if it did not appear normal or healthy, or died prior to harvest. After emergence and initial plant growth (roughly 30 to $60 \mathrm{~cm}$ in size), terminal leaf tissue was collected from approximately $88 \%$ of plants that emerged from Lso haplotype A and B potato seed tubers and from approximately $37 \%$ of plants that emerged from the healthy potato seed tubers (limit was made due to large number of noninoculated control plants). All plant material was taken back to the laboratory for molecular analyses.

Harvest and processing of daughter tubers. At the end of both seasons, daughter tubers generated from each noninfected (healthy), Lso haplotype A-infected, or Lso haplotype B-infected seed potato tuber were harvested by hand and collected into harvest bags by individual plant. Plants were harvested approximately 125 and 152 days after planting for 2015 and 2016, respectively. Following harvest, total yield $(\mathrm{kg})$ and total number of tubers generated from each mother tuber were recorded. A subset of up to three daughter tubers from each plant (however, not all plants produced three daughter tubers) were assessed for the presence of ZC disease symptoms by bisecting the stem end of each tuber and determining if $\mathrm{ZC}$ symptoms were absent ( present (score varied from 1 to 3) (Rashed et al. 2013; Swisher Grimm et al. 2018). The stem-end piece $(\sim 1 \mathrm{~g})$ from one of the three cut tubers was rinsed in water and saved for subsequent molecular analysis in the laboratory.

Molecular detection of Lso in tuber and leaf tissue. All leaf tissue and tuber samples were processed using the same extraction and polymerase chain reaction (PCR) methods. Briefly, total nucleic acids were extracted using a modified cetyltrimethylammonium bromide protocol (Munyaneza et al. 2010). All nucleic acid samples were resuspended in $100 \mu \mathrm{l}$ of water prior to all PCR analyses.

For the detection of Lso in leaf and tuber samples, conventional PCR was used with primers OA2 and OI2c (Crosslin et al. 2011). To distinguish between the specific Lso haplotype, A or B, conventional PCR with primers SSR-1F and SSR-1R was used (Lin et al. 2012; Wen et al. 2013). For both PCR reactions, the total volume was $25 \mu \mathrm{l}$, which included $5 \mu \mathrm{l}$ of GoTaq Green PCR buffer, $0.25 \mu \mathrm{l}$ of $10 \mathrm{mM}$ dNTPs, $0.5 \mu \mathrm{l}$ of each primer $(20 \mu \mathrm{M}), 17.65 \mu \mathrm{l}$ of $\mathrm{H}_{2} \mathrm{O}, 0.1 \mu \mathrm{l}$ of GoTaq DNA polymerase (Promega, Madison, WI), and $1 \mu \mathrm{l}$ of the nucleic acid extraction. Thermal cycle conditions for PCR with primers OA2/OI2c were $94^{\circ} \mathrm{C}$ for $2 \mathrm{~min}$, followed by 40 cycles of $94^{\circ} \mathrm{C}$ for $30 \mathrm{~s}, 65^{\circ} \mathrm{C}$ for $30 \mathrm{~s}$, and $72^{\circ} \mathrm{C}$ for $1 \mathrm{~min}$, and a

Table 1. Seed potato treatments for five cultivars in the 2 -year study ${ }^{a}$

\begin{tabular}{|c|c|c|c|c|}
\hline \multirow[b]{2}{*}{ Treatment } & \multicolumn{2}{|r|}{2015} & \multicolumn{2}{|r|}{2016} \\
\hline & $N$ & $\begin{array}{c}\text { Mean symptom } \\
\text { severity of } \\
\text { seed tubers }\end{array}$ & $N$ & $\begin{array}{c}\text { Mean symptom } \\
\text { severity of } \\
\text { seed tubers }\end{array}$ \\
\hline \multicolumn{5}{|l|}{ Atlantic } \\
\hline Noninfected & 3 & 0 & 3 & 0 \\
\hline Lso haplotype A & 9 & 2.86 & 3 & 2.96 \\
\hline Lso haplotype B & 9 & 3 & 9 & 2.83 \\
\hline \multicolumn{5}{|l|}{ Ranger } \\
\hline Noninfected & 3 & 0 & 3 & 0 \\
\hline Lso haplotype A & 9 & 2.93 & 5 & 2.85 \\
\hline Lso haplotype B & 9 & 2.89 & 9 & 3 \\
\hline \multicolumn{5}{|l|}{ Umatilla } \\
\hline Noninfected & 3 & 0 & 3 & 0 \\
\hline Lso haplotype A & 9 & 2.72 & 6 & 1.65 \\
\hline Lso haplotype B & 9 & 2.97 & 9 & 1.83 \\
\hline \multicolumn{5}{|l|}{ Burbank } \\
\hline Noninfected & 3 & 0 & 3 & 0 \\
\hline Lso haplotype A & 8 & 2.78 & 9 & 2.88 \\
\hline Lso haplotype B & 9 & 3 & 9 & 2.99 \\
\hline \multicolumn{5}{|l|}{ Norkotah } \\
\hline Noninfected & 3 & 0 & 3 & 0 \\
\hline Lso haplotype A & 8 & 2.39 & 6 & 2.96 \\
\hline Lso haplotype B & 9 & 2.92 & 9 & 2.92 \\
\hline
\end{tabular}

a The number $(N)$ of cages planted with either noninfected, 'Candidatus Liberibacter solanacearum' (Lso) haplotype A-infected, or Lso haplotype B-infected seed varied for cultivar and year depending upon availability of tubers. The mean symptom severity of seed potatoes was generated from scoring each bisected seed potato for zebra chip symptom severity (scale of 0 to 3 ). 
final elongation step of $72^{\circ} \mathrm{C}$ for 5 min. PCR products were run on a $1.5 \%$ agarose gel with ethidium bromide staining for visualization of the 1,168-base pair band. Thermal cycle conditions for PCR with primers SSR-1F/SSR-1R were $94^{\circ} \mathrm{C}$ for $5 \mathrm{~min}$, followed by 35 cycles of $94^{\circ} \mathrm{C}$ for $30 \mathrm{~s}, 55^{\circ} \mathrm{C}$ for $30 \mathrm{~s}$, and $72^{\circ} \mathrm{C}$ for $45 \mathrm{~s}$, and a final elongation step of $72^{\circ} \mathrm{C}$ for $10 \mathrm{~min}$. PCR products were run on a $2 \%$ agarose gel with ethidium bromide staining for visualization of the 240- and 180-base pair bands for Lso haplotypes A and B, respectively. Control Lso-positive nucleic acid extractions with Lso haplotype A and/ or haplotype B were included in each PCR reaction, as well as a notemplate, $\mathrm{H}_{2} \mathrm{O}$ negative control.

Statistical analysis. All statistical analyses were performed using the GLIMMIX procedure of SAS 9.4 (SAS Institute, Cary, NC). Response variables for analyses included emergence rate, emergence
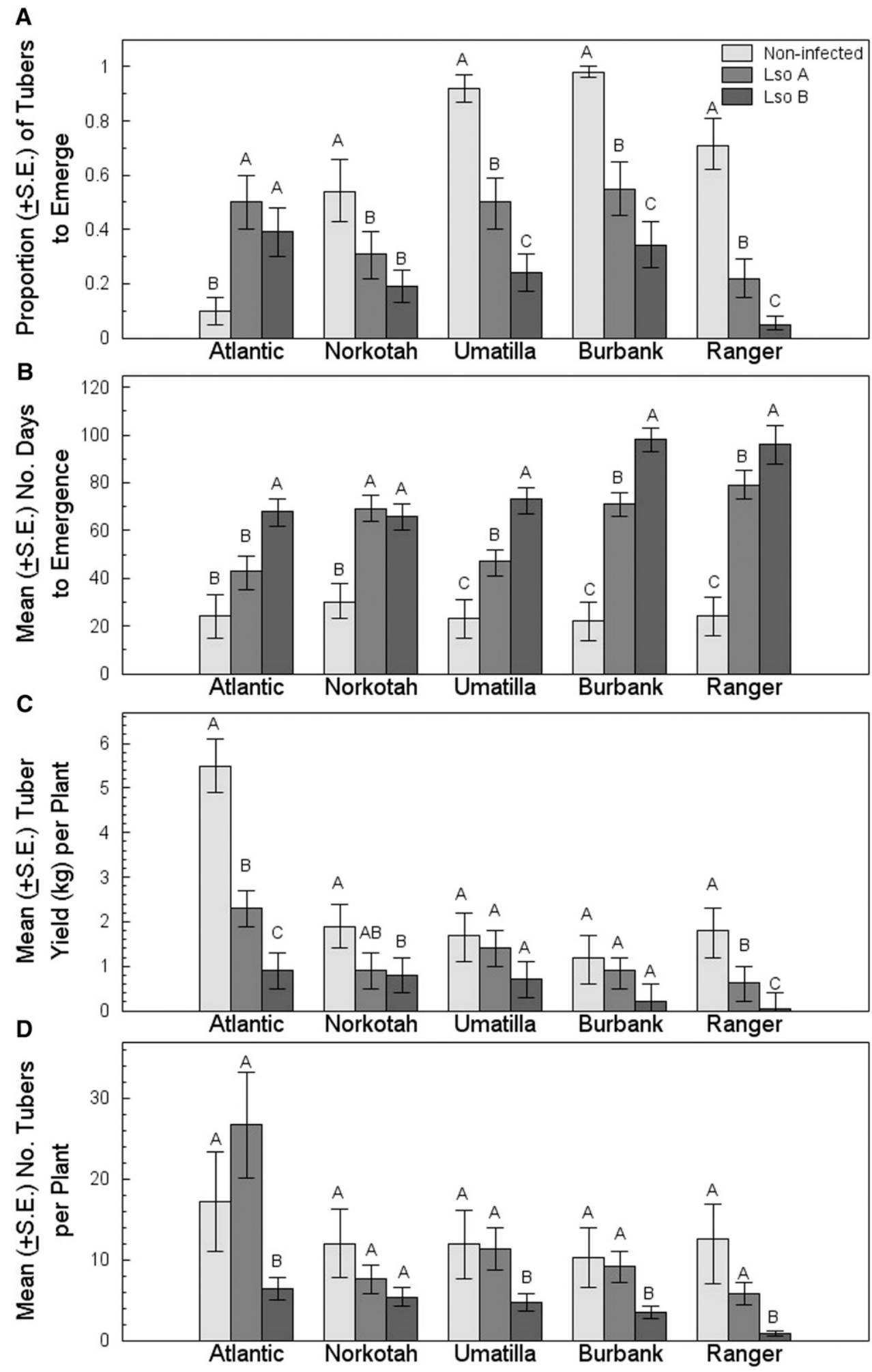

Fig. 1. Infection with 'Candidatus Liberibacter solanacearum' (Lso) haplotype A and B effects plant emergence and daughter tuber formation compared with noninfected control seed potato tubers. The proportion ( \pm standard error) of tubers to have plants emerge $(\mathbf{A})$, mean ( \pm standard error) number of days to emergence $(\mathbf{B})$, mean $( \pm$ standard error) tuber yield $(\mathrm{kg})$ per plant $(\mathbf{C})$, and mean ( \pm standard error) number of tubers produced per plant (D) were analyzed from noninfected, Lso A-infected, and Lso B-infected seed potatoes of five cultivars in a 2-year trial. Uppercase letters indicate significant differences in Lso treatments for each cultivar. 
time (days), weight $(\mathrm{kg})$ of tubers produced by plants, and number of tubers produced by plants. The mean values from the eight plants in each cage were included in the analyses. Emergence rate was examined as a logistic variable using the number of emerged plants divided by the total number of seed tuber plants in a given cage. Days to emergence and tuber weight were examined assuming a normal distribution (DIST $=\mathrm{G}$ of the MODEL statement), whereas tuber number or tubers per plant was examined assuming a negative binomial distribution for count data (DIST $=$ NB of the MODEL statement). The fixed effects in each analysis included potato cultivar, infection status, and the main effect interaction, and year was included as a random variable. When the interaction term was significant, differences among means were estimated using the SLICEDIFF option of the LSMEANS statement with a Tukey's adjustment for multiple comparisons (ADJUST $=$ TUKEY) to compare means among treatments of each cultivar.

\section{Results}

Plant emergence. There was a significant main effect interaction for plant emergence rate, indicating that the effects of Lso infection on tuber sprouting were not consistent among cultivars $\left(F_{8,177}=\right.$ $10.68 ; P<0.0001)$. Identical trends in emergence rates were observed for all cultivars, except Atlantic. For these cultivars (Norkotah, Umatilla, Burbank, and Ranger), a greater proportion of

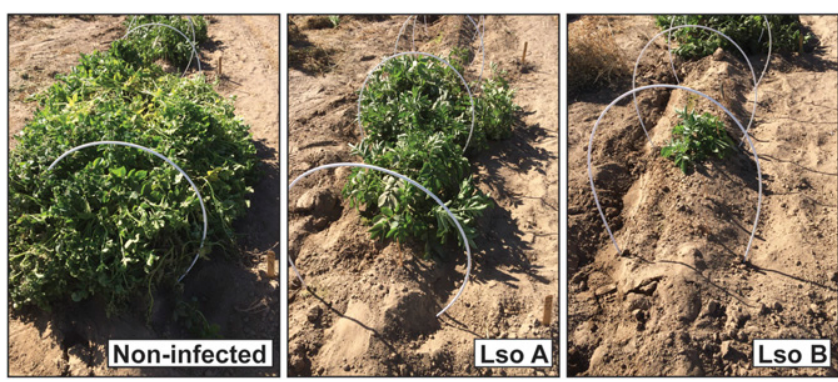

Fig. 2. Plants generally emerged faster from noninfected seed potatoes compared with plants emerging from seed infected with 'Candidatus Liberibacter solanacearum' (Lso) haplotype $A$ and those infected with Lso haplotype B. Images capture plant size and health at harvest in 2015 for the noninfected, Lso A, and Lso B treatments in the Umatilla cultivar. noninfected tubers produced plants compared with the Lso-infected tubers, regardless of Lso haplotype, and a greater proportion of tubers infected with Lso haplotype A successfully emerged compared with tubers infected with Lso haplotype B (Fig. 1A). For the Atlantic cultivar, emergence rates did not differ significantly between the Lso haplotype A and haplotype B seed potatoes, but only a small proportion of noninfected tubers produced plants due to a secondary infection.

A significant cultivar by Lso treatment interaction was also observed for emergence time $\left(F_{8,147.1}=3.49 ; P=0.0010\right)$. Noninfected tubers produced aboveground plants in 20 to 30 days regardless of cultivar, which was significantly shorter than tubers infected with Lso regardless of haplotype, for all cultivars except Atlantic (Fig. 1B). In all cultivars except Norkotah, tubers infected with Lso haplotype A produced plants 20 to 30 days earlier than those infected with Lso haplotype B (Fig. 1B). The delay in number of days to emergence for tubers infected with Lso haplotype B compared with Lso haplotype A, and even more so with the uninoculated control tubers, was evident in plant size at the time of harvest (Fig. 2).

Daughter tuber yield and count. Analysis of the mean daughter tuber yield $(\mathrm{kg})$ per plant identified a significant cultivar by Lso treatment interaction in this 2-year study $\left(F_{8,176}=4.55 ; P<0.0001\right)$. Plants grown from noninfected seed potatoes produced greater yield than did plants grown from Lso-infected tubers, but this trend was significantly different only for the cultivars Atlantic, Norkotah, and Ranger (Fig. 1C). Greater yields were also produced by Atlantic and Ranger plants grown from seed potatoes infected with Lso haplotype A compared with those infected with Lso haplotype B, and Norkotah tubers infected with Lso haplotype A produced yields intermediate to noninfected seed potatoes or seed potatoes infected with Lso haplotype B (Fig. 1C).

A significant cultivar by Lso treatment interaction was identified for the mean number of daughter tubers produced per plant in the 2-year study $\left(F_{8,147}=2.13 ; P=0.0360\right)$. For all cultivars except Norkotah, plants grown from seed potatoes infected with Lso haplotype B produced significantly fewer daughter tubers than did noninfected plants or plants infected with Lso haplotype A (Fig. 1D).

Lso testing of leaf tissue and daughter tubers. Although Lso A- and Lso B-infected tubers tended to have a slower emergence rate compared with noninfected tubers, plants emerging from Lsoinfected seed potato tubers were healthy looking (Fig. 2). None of

Table 2. Detection of 'Candidatus Liberibacter solanacearum' (Lso) in leaf tissue and daughter tubers ${ }^{\mathrm{a}}$

\begin{tabular}{|c|c|c|c|c|}
\hline \multirow[b]{2}{*}{ Treatment } & \multicolumn{2}{|c|}{2015} & \multicolumn{2}{|c|}{2016} \\
\hline & $\begin{array}{l}\text { Lso detection in } \\
\text { leaf tissue }\end{array}$ & $\begin{array}{c}\text { Lso detection in } \\
\text { daughter tuber tissue }\end{array}$ & $\begin{array}{l}\text { Lso detection in } \\
\text { leaf tissue }\end{array}$ & $\begin{array}{c}\text { Lso detection in } \\
\text { daughter tuber tissue }\end{array}$ \\
\hline \multicolumn{5}{|l|}{ Atlantic } \\
\hline Noninfected & $0 / 2$ & $0 / 2$ & $0 / 4$ & $0 / 3$ \\
\hline Lso haplotype A & $0 / 30$ & $0 / 25$ & $0 / 11$ & $0 / 16$ \\
\hline Lso haplotype B & $0 / 10$ & $0 / 8$ & $0 / 30$ & $0 / 43$ \\
\hline \multicolumn{5}{|l|}{ Ranger } \\
\hline Noninfected & $0 / 3$ & $0 / 15^{\mathrm{b}}$ & $0 / 4$ & $0 / 12$ \\
\hline Lso haplotype A & $0 / 12$ & $0 / 9$ & $0 / 10$ & $0 / 10$ \\
\hline Lso haplotype B & $0 / 2$ & $0 / 1$ & $0 / 6$ & $0 / 6$ \\
\hline \multicolumn{5}{|l|}{ Umatilla } \\
\hline Noninfected & $0 / 5$ & $0 / 15^{\mathrm{b}}$ & $0 / 14$ & $0 / 20$ \\
\hline Lso haplotype A & $0 / 37$ & $0 / 28$ & $0 / 18$ & $0 / 22$ \\
\hline Lso haplotype B & $0 / 10$ & $0 / 5$ & $0 / 18$ & $0 / 18$ \\
\hline \multicolumn{5}{|l|}{ Burbank } \\
\hline Noninfected & $0 / 3$ & $0 / 15^{\mathrm{b}}$ & $0 / 4$ & $0 / 24$ \\
\hline Lso haplotype A & $0 / 28$ & $0 / 21$ & $0 / 37$ & $0 / 38$ \\
\hline Lso haplotype B & $0 / 13$ & $1 / 8$ & $0 / 27$ & $0 / 26$ \\
\hline \multicolumn{5}{|l|}{ Norkotah } \\
\hline Noninfected & $0 / 4$ & $0 / 15^{\mathrm{b}}$ & $0 / 5$ & $0 / 5$ \\
\hline Lso haplotype A & $0 / 19$ & $0 / 14$ & $0 / 13$ & $0 / 16$ \\
\hline Lso haplotype B & $0 / 8$ & $0 / 8$ & $0 / 16$ & $0 / 16$ \\
\hline
\end{tabular}

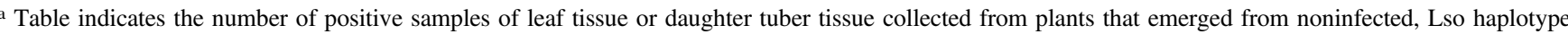
A-infected, or Lso haplotype B-infected seed potatoes out of the total number of samples tested for Lso by conventional PCR.

${ }^{\mathrm{b}}$ For some noninfected controls, only a subset of daughter tubers from the total number of emerged plants were tested for Lso. 
the plants that emerged from Lso A- or Lso B-infected seed potatoes produced aboveground symptoms characteristic of ZC. Plant tissues that emerged from the noninfected control, Lso A-infected, and Lso B-infected seed potatoes were tested for Lso by conventional PCR in 2015 and 2016 (Table 2). In both years, no plants tested positive from any Lso treatment.

Daughter tubers from all plants were scored for ZC symptoms of vascular darkening, spotting, and discoloration. No ZC symptoms were observed from any of the daughter tubers from Lso haplotype A- or haplotype B-infected seed potato tubers (Fig. 3). At least one tuber per plant was sampled from Lso haplotype A- or haplotype B-infected treatments to detect Lso using conventional PCR methods (Table 2). In 2015, a single daughter tuber (Burbank cultivar, Lso Binfected seed potato tuber) from a total of 127 Lso haplotype A- or haplotype B-infected plants was positive for Lso (0.8\%). In 2016, no Lso haplotype A- or haplotype B-infected tubers from a total of 211 were positive for Lso using conventional PCR.

\section{Discussion}

The purpose of this 2-year study was to compare the germination success, growth, and yield of plants produced from noninfected seed potatoes to those infected with either Lso haplotype A or B in five common U.S. potato cultivars (including one chipping cultivar and four russet cultivars). Overall, results suggest that seed tubers exhibiting severe ZC symptoms caused by both Lso haplotypes A and B cause lower emergence rates and delayed emergence, leading to lower daughter tuber yield and number of tubers produced when compared with healthy tubers free of ZC symptoms. Lso haplotype B appeared more virulent than Lso haplotype A, with a lower proportion of plant emergence, greater number of days to emergence, lower tuber yield, and lower tuber count generated from Lso B-infected seed potato tubers exhibiting severe ZC symptoms. Variability was predominantly seen with the Atlantic cultivar, where poor emergence of the noninfected controls was due to presence of a secondary bacterial infection destroying the noninoculated control tubers. The Lso-infected tubers were not affected by this secondary bacterial infection, suggesting a difference in tuber physiology, possibly due to the presence of Lso.

These findings support the results from two previous studies by Henne et al. (2010) and Rashed et al. (2015), in which less than $50 \%$ of ZC-symptomatic tubers sprouted. Additionally, these findings support the differences in Lso haplotype epidemiology identified in our previous study (Swisher Grimm et al. 2018), in which currentseason infection with Lso haplotype B, regardless of the haplotype of the psyllid vector, was associated with a greater incidence of $\mathrm{ZC}$, more severe tuber symptoms, and reduced tuber yield and numbers.

Results from this current study suggest that plant emergence from Lso A- or Lso B-infected seed potatoes exhibiting severe ZC

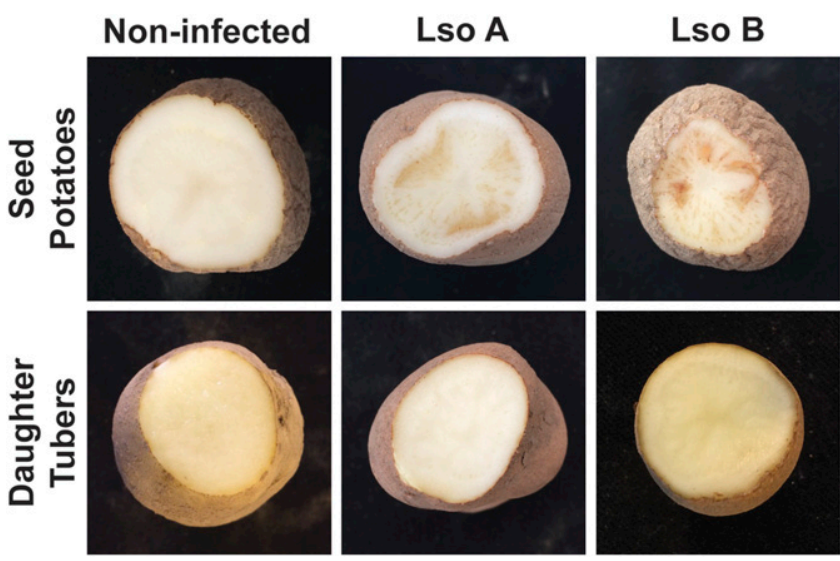

Fig. 3. No visual zebra chip (ZC) symptoms were detected in daughter tubers harvested from 'Candidatus Liberibacter solanacearum' (Lso) haplotype A- and haplotype B-infected seed potatoes. Despite seed potatoes showing severe ZC symptoms for the Lso A- and Lso B-infected tubers, disease symptoms were absent in daughter tubers for all cultivars. symptoms is likely not a significant source of Lso infection in potato fields. Lso was not detected from leaf tissue collected from plants that emerged from Lso A- or Lso B-infected seed potatoes in this 2-year study. This absence of detectable Lso in above-ground foliage is in contrast to the results seen from a similar study in New Zealand, in which nearly $70 \%$ of asymptomatic leaf tissue that emerged from Lso haplotype A-infected mother tubers (with unknown symptom severity) tested positive for the pathogen (Pitman et al. 2011). It is possible that potato cultivar or environmental conditions such as weather events, soil temperature, or growing degree days could account for differences in the production of Lso-positive foliage between studies, although this is entirely speculative. Regardless, the detection of Lso in only a single daughter tuber generated from an Lso B-infected seed potato in this 2-year study provides further support that Lso movement from infected seed to newly emerging plants (above-ground foliage and daughter tubers) is not a likely source of Lso infection in U.S. potato fields.

The lower emergence rate in Lso A- and Lso B-infected tubers exhibiting severe ZC symptoms, as well as the greater number of days to emergence in these Lso treatments, suggest that commercial potato growers in the Pacific Northwest, where this trial was completed, and perhaps across the United States, should not be concerned with planting a small percentage of Lso-infected seed. As long as the majority of seed planted is Lso-free, any low percentage of plants that do emerge from infected seed will be quickly choked out by the healthy-growing, noninfected plants nearby. In a large commercial potato field, the probability of a very small percentage of symptomatic, Lso-infected plants emerging from seed and generating an adequate, persistent supply of Lso for the potato psyllid vector to transmit is likely negligible, based on the results from this current study. An assessment of the ability of potato psyllids to acquire Lso from plants that emerge from Lsoinfected seed would be needed to confirm this.

\section{Acknowledgments}

We thank Millie Heidt, Stacey Pettit, Shane Balcom, and Francisco de la Rosa for their technical support in the field. We thank Becky Cochran for her technical support in the laboratory.

\section{Literature Cited}

Alfaro-Fernández, A., Hernández-Llopis, D., and Font, M. I. 2017. Haplotypes of 'Candidatus Liberibacter solanacearum' in umbeliferous crops in Spain. Eur. J. Plant Pathol. 149:127-131.

Alfaro-Fernández, A., Siverio, F., Cebrián, M. C., Villaescusa, F. J., and Font, M. I. 2012. 'Candidatus Liberibacter solanacearum' associated with Bactericera trigonica-affected carrots in the Canary Islands. Plant Dis. 96:581.

CNAS. 2006. Economic impacts of zebra chip on the Texas potato industry. Center for North American Studies, http://cnas.tamu.edu/zebra\%20chip\%20impacts\% 20final.pdf.

Cooper, W. R., Horton, D. R., Miliczky, E., Wohleb, C. H., and Waters, T. D. 2019. The weed link in zebra chip epidemiology: Suitability of non-crop Solanaceae and Convolvulaceae to potato psyllid and "Candidatus Liberibacter solanacearum". Am. J. Potato Res. 96:262-271.

Cooper, W. R., Swisher, K. D., Garczynski, S. F., Mustafa, T., Munyaneza, J. E., and Horton, D. R. 2015. Wolbachia infection differs among divergent mitochondrial haplotypes of Bactericera cockerelli (Hemiptera: Triozidae). Ann. Entomol. Soc. Am. 108:137-145.

Crosslin, J. M., Hamm, P. B., Eggers, J. E., Rondon, S. I., Sengoda, V. G., and Munyaneza, J. E. 2012a. First report of zebra chip disease and "Candidatus Liberibacter solanacearum" on potatoes in Oregon and Washington State. Plant Dis. 96:452.

Crosslin, J. M., Lin, H., and Munyaneza, J. E. 2011. Detection of 'Candidatus Liberibacter solanacearum' in the potato psyllid, Bactericera cockerell (Sulc), by conventional and real-time PCR. Southwest. Entomol. 36:125-135.

Crosslin, J. M., Olsen, N., and Nolte, P. 2012b. First report of zebra chip disease and "Candidatus Liberibacter solanacearum" on potatoes in Idaho. Plant Dis. 96:453.

Dahan, J., Wenninger, E. J., Thompson, B., Eid, S., Olsen, N., and Karasev, A. V. 2017. Relative abundance of potato psyllid haplotypes in southern Idaho potato fields during 2012 to 2015, and incidence of 'Candidatus Liberibacter solanacearum' causing zebra chip disease. Plant Dis. 101:822-829.

Greenway, G. A., and Rondon, S. 2018. Economic impacts of zebra chip in Idaho, Oregon, and Washington. Am. J. Potato Res. 95:362-367.

Haapalainen, M., Latvala, S., Rastas, M., Wang, J., Hannukkala, A., Pirhonen, M., and Nissinen, A. I. 2018a. Carrot pathogen 'Candidatus Liberibacter solanacearum' haplotype $\mathrm{C}$ detected in symptomless potato plants in Finland. Potato Res. 61:31-50. 
Haapalainen, M., Wang, J., Latvala, S., Lehtonen, M. T., Pirhonen, M., and Nissinen, A. I. 2018b. Genetic variation of 'Candidatus Liberibacter solanacearum' haplotype $\mathrm{C}$ and identification of a novel haplotype from Trioza urticae and stinging nettle. Phytopathology 108:925-934.

Harrison, K., Tamborindeguy, C., Scheuring, D. C., Herrera, A. M., Silva, A., Badillo-Vargas, I. E., Miller, J. C., and Levy, J. G. 2018. Differences in zebra chip severity between 'Candidatus Liberibacter solanacearum' haplotypes in Texas. Am. J. Potato Res. 96:86-93.

Henne, D. C., Workneh, F., Wen, A., Price, J. A., Pasche, J. S., Gudmestad, N. C., and Rush, C. M. 2010. Characterization and epidemiological significance of potato plants grown from seed tubers affected by zebra chip disease. Plant Dis. 94:659-665

Henrickson, A., Kalischuk, M., Lynn, J., Meers, S., Johnson, D., and Kawchuk, L. 2019. First report of zebra chip on potato in Canada. Plant Dis. 103:1016.

Holeva, M. C., Glynos, P. E., and Karafla, C. D. 2017. First report of 'Candidatus Liberibacter solanacearum' on carrot in Greece. Plant Dis. 101:1819.

Horton, D. R., Miliczky, E., Munyaneza, J. E., Swisher, K. D., and Jensen, A. S. 2014. Absence of photoperiod effects on mating and ovarian maturation by three haplotypes of potato psyllid, Bactericera cockerelli (Hemiptera: Triozidae). J. Entomol. Soc. B.C. 111:1-12.

Liefting, L. W., Perez-Egusquiza, Z. C., Clover, G. R. G., and Anderson, J. A. D. 2008. A new 'Candidatus Liberibacter' species in Solanum tuberosum in New Zealand. Plant Dis. 92:1474.

Lin, H., Islam, M. S., Bai, Y., Wen, A., Lan, S., Gudmestad, N. C., and Civerolo, E. L. 2012. Genetic diversity of 'Candidatus Liberibacter solanacearum' strains in the United States and Mexico revealed by simple sequence repeat markers. Eur. J. Plant Pathol. 132:297-308.

Liu, D., Trumble, J. T., and Stouthamer, R. 2006. Genetic differentiation between eastern populations and recent introductions of potato psyllid (Bactericera cockerelli) into western North America. Entomol. Exp. Appl. 118:177-183.

Mendoza-Herrera, A., Levy, J., Harrison, K., Yao, J., Ibnez, F., and Tamborindeguy, C. 2018. Infection by Candidatus Liberibacter solanacearum haplotypes A and B in Solanum lycopersicum 'Moneymaker'. Plant Dis. 102: 2009-2015.

Munyaneza, J. E. 2012. Zebra Chip disease of potato: Biology, epidemiology, and management. Am. J. Potato Res. 89:329-350.

Munyaneza, J. E., Crosslin, J. M., and Upton, J. E. 2007a. Association of Bactericera cockerelli (Homoptera: Psyllidae) with "zebra chip", a new potato disease in southwestern United States and Mexico. J. Econ. Entomol. 100:656-663.

Munyaneza, J. E., Fisher, T. W., Sengoda, V. G., Garczynski, S. F., Nissinen, A., and Lemmetty, A. 2010. Association of "Candidatus Liberibacter solanacearum" with the psyllid, Trioza apicalis (Hemiptera: Triozidae) in Europe. J. Econ. Entomol. 103:1060-1070.

Munyaneza, J. E., Goolsby, J. A., Crosslin, J. M., and Upton, J. E. 2007b. Further evidence that zebra chip potato disease in the lower Rio Grande Valley of Texas is associated with Bactericera cockerelli. Subtrop. Plant Sci. 59:30-37.

Munyaneza, J. E., Lemmetty, A., Nissinen, A. I., Sengoda, V. G., and Fisher, T. W. 2011. Molecular detection of aster yellows phytoplasma and "Candidatus Liberibacter solanacearum" in carrots affected by the psyllid Trioza apicalis (Hemiptera: Triozidae) in Finland. J. Plant Pathol. 93:697-700.

Mustafa, T., Horton, D. R., Cooper, W. R., Swisher, K. D., Zack, R. S., and Munyaneza, J. E. 2015a. Interhaplotype fertility and effects of host plant on reproductive traits of three haplotypes of Bactericera cockerelli (Hemiptera: Triozidae). Environ. Entomol. 44:300-308

Mustafa, T., Horton, D. R., Cooper, W. R., Swisher, K. D., Zack, R. S., Pappu, H. R., and Munyaneza, J. E. 2015b. Use of electrical penetration graph technology to examine transmission of 'Candidatus Liberibacter solanacearum' to potato by three haplotypes of potato psyllid (Bactericera cockerelli; Hemiptera: Triozidae). PLoS One 10:e138946.

Nelson, W. R., Fisher, T. W., and Munyaneza, J. E. 2011. Haplotypes of "Candidatus Liberibacter solanacearum" suggest long-standing separation. Eur. J. Plant Pathol. 130:5-12

Nelson, W. R., Sengoda, V. G., Alfaro-Fernandez, A. O., Font, M. I., and Crosslin, J. M. 2013. A new haplotype of 'Candidatus Liberibacter solanacearum' identified in the Mediterranean region. Eur. J. Plant Pathol. 135:633-639.

Pitman, A. R., Drayton, G. M., Kraberger, S. J., Genet, R. A., and Scott, I. A. W. 2011. Tuber transmission of 'Candidatus Liberibacter solanacearum' and its association with zebra chip on potato in New Zealand. Eur. J. Plant Pathol. 129:389-398.

Rashed, A., Wallis, C. M., Paetzold, L., Workneh, F., and Rush, C. M. 2013. Zebra chip disease and potato biochemistry: Tuber physiological changes in response to 'Candidatus Liberibacter solanacearum' infection over time. Phytopathology 103:419-426.

Rashed, A., Workneh, F., Paetzold, L., and Rush, C. M. 2015. Emergence of 'Candidatus Liberibacter solanacearum'-infected seed potato in relation to the time of infection. Plant Dis. 99:274-280.

Secor, G. A., Rivera-Varas, V., Abad, J. A., Lee, I. M., Clover, G. R. G., Liefting, L. W., Li, X., and De Boer, S. H. 2009. Association of 'Candidatus Liberibacter solanacearum' with zebra chip disease of potato established by graft and psyllid transmission, electron microscopy, and PCR. Plant Dis. 93:574-583.

Swisher, K. D., Henne, D. C., and Crosslin, J. M. 2014. Identification of a fourth haplotype of Bactericera cockerelli (Hemiptera: Triozidae) in the United States. J. Insect Sci. 14:161.

Swisher, K. D., Munyaneza, J. E., and Crosslin, J. M. 2012. High resolution melting analysis of the cytochrome oxidase I gene identified three haplotypes of the potato psyllid in the United States. Environ. Entomol. 41:1019-1028.

Swisher Grimm, K. D., and Garczynski, S. 2019. Identification of a new haplotype of 'Candidatus Liberibacter solanacearum' in Solanum tuberosum. Plant Dis. 103:468-474.

Swisher Grimm, K. D., Mustafa, T., Cooper, W. R., and Munyaneza, J. E. 2018 Role of 'Candidatus Liberibacter solanacearum' and Bactericera cockerelli haplotypes in zebra chip incidence and symptom severity. Am. J. Potato Res. 95:709-719.

Tahzima, R., Maes, M., Achbani, E. H., Swisher, K. D., Munyaneza, J. E., and De Jonghe, K. 2014. First report of 'Candidatus Liberibacter solanacearum' on carrot in Africa. Plant Dis. 98:1426.

Teresani, G. R., Bertolini, E., Alfaro-Fernández, A., Martínez, C., Tanaka F. A. O., Kitajima, E. W., Roselló, M., Sanjuán, S., Ferrándiz, J. C., López, M. M., Cambra, M., and Font, M. I. 2014. Association of 'Candidatus Liberibacter solanacearum' with a vegetative disorder of celery in Spain and development of a real-time PCR method for its detection. Phytopathology 104:804-811.

Wen, A., Johnson, C., and Gudmestad, N. C. 2013. Development of a PCR assay for the rapid detection and differentiation of 'Candidatus Liberibacter solanacearum' haplotypes and their spatiotemporal distribution in the United States. Am. J. Potato Res. 90:229-236. 